\title{
Catastrophic decline and subsequent conservation management of the Critically Endangered Fatu Hiva Monarch Pomarea whitneyi in the Marquesas Islands (French Polynesia)
}

\author{
THOMAS GHESTEMME D, ARTHUR MATOHI, CAROLINE BLANVILLAIND, \\ EMMANUELLE PORTIER, MADEN LE BARH and MARK O'BRIEN
}

\begin{abstract}
Summary
This paper documents the catastrophic decline of the 'Critically Endangered' Fatu Hiva Monarch Pomarea whitneyi since 2000 and presents population dynamics and conservation actions for the species between 2008 and 2017. The Fatu Hiva Monarch conservation programme has prevented the extinction of the species thus far. However, after an initial increase in the population size within the management area between 2008 and 2012, recruitment subsequently declined. Improvements in the method of trapping to control cats in 2016 and 2017 coincided with encouraging results in terms of juvenile monarch survival rates, although two adult birds disappeared during the same period. The initial hypothesis, that the population would recover once the main threat, black (or ship) rat Rates Rattus predation, was effectively controlled in the breeding territories, has not proved to be correct. An alternative hypothesis assumes that cat predation, mainly on young birds, is limiting monarch recovery. Control of feral cats has been undertaken since 2010, but the implementation of a new trapping method (leg-hold traps) combined with a significant increase in cat trapping effort, has coincided with an increase in the number of cats culled, as well as monarch post-fledging survival in 2016 and 2017. For the first time in the project, no mortality has been observed for monarch chicks, fledged juveniles or immature birds. If this alternative hypothesis holds, we would expect to recruit young birds into the monarch population in the next year or two. First, this will reduce the likelihood that the Fatu Hiva Monarch will become extinct and second, provide a source population to either repopulate the island following the eradication of rats and cats or to translocate birds to a rat and cat free island.
\end{abstract}

\section{Introduction}

The avifauna of the Pacific islands has been impacted ever since humans first arrived, leading to the extinction of several endemic forms and drastic restrictions in the range of many species (Collar et al. 1994, Steadman 2006). These impacts are still ongoing (Thibault and Cibois 2017). Monarch flycatchers of the genus Pomarea (Aves) constitute a good example of the loss of terrestrial biodiversity in island ecosystems. They are restricted to Eastern Polynesia in the South Pacific, with one 'Critically Endangered' species (Tahiti Monarch P. nigra) comprising 60 individuals in 2016 (Blanvillain et al. 2017) and one 'Extinct' in the Society Islands (Maupiti Monarch P. pomarea). Three species are extant in the Marquesas Islands, all under a high risk of extinction - Marquesas 
Monarch P. mendozae on Mohotani island ('Endangered'), Iphis Monarch P. iphis on Ua Huka ('Critically Endangered'), and Fatu Hiva Monarch P. whitneyi on Fatu Hiva ('Critically Endangered'). Ua Pou Monarch P. mira is classified as 'Critically Endangered (Possibly Extinct)' but is now believed to be extinct. Two species, NuKu Hiva Monarch P. nukuhivae and Eiao Monarch P. fluxa, are confirmed to be 'Extinct', as is the subspecies Marquesas Monarch P. mendozae mendozae on Hiva Oa and Tahuata (Thibault and Meyer 2001, Cibois et al. 2003, BirdLife International 2018). Another monarch species in the Cook Islands, formerly down to seven pairs in 1987/88 and considered 'Critically Endangered', is currently in excess of 500 birds as a result of intensive conservation action and has been down-listed to 'Vulnerable' (BirdLife International 2018). Introduced black or ship rats Rates Rattus are known to predate heavily on bird nests, causing decline and extinction of Pomarea species and subspecies on all islands they occur (Robertson et al. 1994, Thibault et al. 2002).

Fatu Hiva Monarch Pomarea whitneyi (Murphy and Mathews 1928), or Oma'o in Marquesan, is a medium-sized passerine endemic to Fatu Hiva in the Marquesas archipelago. In 1975, the population was estimated at several hundred breeding pairs (Holyoak and Thibault 1984), and the species was still considered common in 1990 (Seitre and Seitre 1992). Although endemic to only one island and classed as 'Vulnerable', the species was considered secure despite the presence of Pacific rat Rattus exulans. However, black rats were accidentally introduced in the late 1980s causing the rapid decline of the monarch population (Thibault and Meyer 2001) and their subsequent uplisting to 'Critically Endangered' in 2000 (BirdLife International 2018). Unlike to 1975, in 2000, no birds were observed in the mango Mangifera indica groves on the slopes and ridges, while a lack of sightings of birds in immature plumage suggested low breeding success (Thibault and Meyer 2001, Thibault and Cibois 2017). Fatu Hiva has been identified as a priority site for mammal eradication in order to prevent extinction of the monarch (Brooke et al. 2007, Nogales et al. 2013).

The aims of this paper are to document the decline of the Fatu Hiva Monarch since 2000 and to present recent population dynamics and conservation actions (control of invasive predator species) undertaken since 2007. First, the paper explores the consequences of rat control in monarch breeding territories, and later whether cat predation on juvenile monarchs could limit population recovery. Previous studies of passerines have indicated that post-fledging survival can significantly influence species population demography (Cox et al. 2014).

We also report on the conservation programme that began in 2007, including the implementation of the Species Action Plan (Ghestemme et al. 2013). Monarch surveys, undertaken at the island scale, and predator control coupled with bird monitoring in a management area, were implemented by the Société d'Ornithologie de Polynésie (SOP-Manu), the BirdLife International partner in French Polynesia.

\section{Methods}

\section{Site}

Fatu Hiva, located at $10^{\circ} 24^{\prime} \mathrm{S} ; 138^{\circ} 4 \mathrm{O}^{\prime} \mathrm{W}$, is the southernmost island of the Marquesas, the wettest in the archipelago with mean annual rainfall around $1,700 \mathrm{~mm}$ and maxima exceeding 4,000 $\mathrm{mm}$ (Laurent 2016). The island is remote, with the nearest airport on Hiva Oa, $75 \mathrm{~km}$ away. Fatu Hiva is relatively well-forested with little overgrazing or destruction by fire. The size of the island is $80 \mathrm{~km}^{2}$, the maximum elevation is Mount Touaouoho $(1,125 \mathrm{~m})$ and the relief is very steep with a volcanic central ridge dividing the island along a north-south axis. The Managed Area, situated in the Omoa valley system on the western side of the island, hosts the last remnant monarch population. Its dense and woody vegetation is dominated by the native Hibiscus tiliaceus in the valley bottom, mixed with Pandanus tectorius and Metrosideros collina on the hillsides. Some banana plantations occur along the streams of the valleys holding the last monarchs. Around 650 inhabitants live in Omoa and Hanavave, two villages on the west coast, 1.2 and $5.5 \mathrm{~km}$ from the 
Managed Area, respectively. The main livelihoods are fishing, copra harvesting, handicraft and hunting goats and wild pigs.

\section{Fatu Hiva Monarch ecology and population monitoring}

\section{Fatu Hiva Monarch ecology:}

The Fatu Hiva Monarch is the largest Pomarea species, with a mean weight of $43.5 \mathrm{~g}$ (40-49 g; $n=17$ in this study), nearly twice the weight of the Tahiti Monarch $(24.6 \mathrm{~g}$, unpubl. data; $n=17)$ and Rarotonga Monarch (23.2 g; Robertson et al. 1993). Their plumage changes with age, similar to Tahiti and Rarotonga Monarchs: adult ( $>3$ years old) males and females are entirely black, sub-adults ( 3 years) are a mix of black and brown, while juvenile and immature birds $(<3$ years) are brown and light grey. The base of the bill is fleshy-yellow in juveniles, completely dark in immatures turn progressively to light grey for adults (pers. obs.). Subadults can breed successfully, while immatures can form a pair but have never been observed breeding successfully. Observations of banded birds showed that similar to other Pomarea species, the Fatu Hiva Monarch is highly territorial. We found that the Fatu Hiva Monarch can breed at any time of the year (unlike the Rarotonga Monarch), with up to two successful breeding events over a 12-month period. Clutch size is one egg (similar to the Tahiti Monarch, while the Rarotonga Monarch can lay two eggs). Incubation period is about 17 days long, chicks remain in the nest for three weeks, and fledglings continue to be fed out of the nest by parents for a minimum of 2.5 months but can stay for up to 10 months in the area of parents' territory (pers. obs.). Juvenile birds that disappeared from the territory less than two months after fledging were never resighted, so are assumed to have failed at that stage. Young Fatu Hiva Monarchs (as with all Pomarea species) are very naive and inquisitive; as soon as they detect humans in the area, they can approach to within $1.5 \mathrm{~m}$ (pers. obs; we have observed the same behaviour for Tahiti Monarch). Additionally, one young Fatu Hiva Monarch was seen to approach a dog to within $1 \mathrm{~m}$ (pers. obs.). Young Fatu Hiva Monarchs also spend time feeding on, or close to, the ground. In a few weeks of observations we recorded 12 images of juveniles in the study area on four separate trail cameras that were positioned to monitor cats.

\section{Monarch survey at the island scale:}

Monarch breeding territories are always centred on streams within valleys (pers. obs.), as observed for Tahiti Monarch Pomarea nigra (pers. obs) and Rarotonga Monarch P. dimidiata (Ed Saul pers. comm.). Surveys on Fatu Hiva were therefore conducted by following streams, from the coast towards the upland, only stopping when the steeply-rising valley terrain became inaccessible. Valleys are mostly narrow and due to the loud calls of the birds and dry stream, birds can be heard from the bed if they are present on the valley slope during the count. During the different surveys, 10-minute point counts have been undertaken every 200 $\mathrm{m}$ up the valley to locate any territory (Bibby et al. 200o). The distances and positions were chosen and recorded using a GPS (Garmin eTrex Vista HCX@). For each point count, if no bird was recorded within the first 5 -minute period, a playback call was used (FoxPro $\mathrm{NX}_{3}$ game hand call@). The number of birds, their plumage and any individually recognisable features were recorded.

The distribution of suitable habitat, defined as Hibiscus tiliaceus-dominated vegetation, was assessed using a high-resolution satellite photograph (IKONOS@) using ArcView vio. 2 software. The territories are centred along streams, and the length of suitable habitat includes both the primary and each of the secondary streams in each of the suitable areas. The Fatu Hiva monarch population size was calculated from 2009 survey data by estimating the total length of streams with suitable habitat in each of the island valleys and extrapolating the mean number of monarchs per unit length of surveyed valley. 


\section{Bird monitoring in the Managed Area:}

We monitored nest and young survival in the Managed Area in 2007-2017 (405 ha: GIS planar area $x$ slope factor of 1.35). The Managed Area covers the current and past distribution of monarchs in the Omoa valley system. The entire area is monitored at least twice a year, with more regular coverage of currently occupied territories. As the species is strongly territorial and emits a loud call, individuals were observed either aurally or visually observation (using $10 \times 42$ binoculars). Within the Managed Area, each monarch territory was monitored at least twice a month, with a minimum of 30 minutes spent in each territory. During the visits we recorded plumage type, the presence of colour-bands on individuals and noted their precise location. Twenty-four birds were colour-banded between 2009 and 2017. Birds were captured by the first author (with an authorisation from the Government of French Polynesia) using a mist-net and call playback using the song of the species.

Monarch breeding behaviour was recorded and, if the presence of a nest was suspected, an intensive search was undertaken. Several workers equipped with VHF radios were simultaneously present in the territory to facilitate location of the nest site on the slopes of dense Hibiscus vegetation. Once nest-building was observed, the nest was monitored at least once per week until the young had fledged. After fledging, young were observed 1-3 times each week. We searched for fledged juveniles for a minimum of 30 minutes in and around the parents' territory per visit. A juvenile was declared dead if it was not observed on five consecutive visits while, at the same time, both parents were observed without any accompanying juveniles. Survival rate estimates assume that mortality occurred after the last positive observation of the juvenile. Even when juveniles are unbanded, it is possible to individually identify them, because of the low number of young present, their behaviour, identification of parents and distinctive plumage. Population parameters compiled for each year include 'nesting success' (number of fledglings per territorial pair) and 'breeding success' (number of young alive at least two months after fledging per territorial pair). The turnover of birds, immigration or emigration/death in territories (changes in the individually-recognised or age composition of the pairs of bird) were monitored and compiled each year for the Managed Area.

\section{Comparison with other species survival rates:}

We compared survival rates of the Fatu Hiva Monarch obtained in this study (adult, nest, fledgling and juvenile recruited in the population) to survival of the two other monarch species. For adult survival rate, we used data from Robertson et al. (1994) for Rarotonga Monarch ( $n=159$ adults) and from Blanvillain et al. (submitted) for Tahiti Monarch ( $n=124$ adults). Robertson et al. (1994) and Blanvillain et al. (submitted) also obtained nest survival data ( $n=71$ for Rarotonga Monarch and $n=55$ for Tahiti Monarch). For the survival of young after fledging, the data presented for Rarotonga Monarch is for survival in the first year $(n=183$, Robertson and Saul 2008). For Tahiti Monarch the survival of young for six weeks after leaving the nest is recorded ( $n=51$, Blanvillain et al. submitted). For the three monarch species, recruitment rates are based on the difference between the theoretical number of birds that fledged in year 1 and the young observed in subsequent years: Rarotonga Monarch $n=163$ in year 1 (Robertson and Saul 2008); Tahiti Monarch $n=74$ young in year I (Blanvillain et al. submitted).

\section{Invasive predator management}

\section{Rat control:}

Rat control started in 2007 in the monarch territories and has been undertaken throughout the year since 2009, as the Fatu Hiva Monarch breeds all year round. Bait stations (MiniPhilproof(C) were located every $20-25 \mathrm{~m}$ in all accessible parts of the valleys, coverage expanding to 143 ha 
(the planar area from GIS is 106 ha, corrected with 1.35 coefficient of slope). Baits were rotated regularly (toxins and forms: pellets, blocks or paste) to prevent bait avoidance and toxin resistance. On the slopes we used Brodifacoum toxin at $0.005 \%$ (Pestoff $20 \mathrm{R} \odot$, Talon All weather blocks $\odot$, ACP Ltd or Final Blox $\odot$, Bell Labs) or $0.002 \%$ (Pestoff rodent blocks $\odot$, ACP Ltd), while near the valley streams we used Diphacinone at $0.005 \%$ (Ratabate $\odot$, Connovation Ltd or Pestoff $50 \mathrm{D} \odot$, ACP Ltd). Bait ( $100 \mathrm{~g}$ ) was placed in plastic bags to reduce mould. These bags were located inside the bait stations and were replenished monthly, with a record kept of the amount of bait uptake. All bait and bags were cleared from the stations and burned. In 2010-2013, we used tracking tunnels to monitor rat abundance, which showed very low density in the rat control area (data not presented). In 2014, we complemented the chemical control by rat trapping with Victor@ snap traps, baited with coconut. We abandoned this in 2015 as checking the traps every two days was very time-consuming.

In the first years of the programme, we attempted to protect all pairs found on the island, even if some were situated in difficult-to-access areas, sometimes requiring a boat to reach valleys furthest from the villages. This intensive protection was undertaken for $2-4$ years, but abandoned for six pairs that appeared to be sterile (building oversized nests, but not laying eggs or raising chicks) and/or after one of the pairs disappeared from the territory. Since 2015 the conservation programme has focused on the Managed Area in the Omoa valley, as this area held the last known actively breeding pairs of the species.

\section{Cat control:}

Feral cat control started in 2010 with kill traps based on those used by the New Zealand Department of Conservation (DOC), who provided training for SOP-Manu staff in 2011 and 2013. Two types of traps were used: Connibear trap Belisle $220^{\prime} \odot$ with protection box in wood designed by DOC and Timm's traps adapted by DOC to target cats (Figure 3). Traps were initially baited with fresh fish, then in 2013 we switched to dried fish which remain appetising for 2-3 days in the field. Consequently, we considered kill traps active for two consecutive nights, and checked them twice a week. Dead cats were removed from the trap and buried. At the end of 2015, the kill traps were removed and replaced by leg-hold traps (Bridger \#2 Rubber Jaw@ from Minnesota Trapline Products Inc.), because of the low capture rate of the kill traps and evidence of the continuous presence of numerous cats in the Managed Area. Leg-hold traps were checked every day of the week, disarmed on Saturday and reset on Monday (five nights of trapping each week). All live cats caught in the leg-hold traps were euthanized and buried. The day of capture, the number and type of active, inactive and successful traps were recorded. These data were used to calculate an index of trapping success per 100 trap nights. The number of trap nights was the number of nights that each active trap was set with palatable bait (Efford and Fewster 2013).

In the villages, domestic cats were sterilised or neutered. These operations were performed by vets from SOP-Manu, following discussions with inhabitants to ensure acceptance of these management actions. Stray cats were either trapped with cages and euthanized, shot at night using a 22LR rifle or poisoned using bait with PredaStop $\odot$ (Connovation Ltd) paste containing PAPP (para-aminoprophenone).

\section{Results}

\section{Invasive predator management}

The management effort within the rat control area increased from 325 rat bait stations on 41 hectares (eight stations per hectare) to 712 stations on 143 hectares in 2016 (five stations per hectare; Table 1), decreasing to 664 stations on 127 ha in 2018 . Only one nest predation incident attributable to rats has occurred during the programme in 2009. 
Table 1. Predator management efforts and results.

\begin{tabular}{|c|c|c|c|c|c|c|c|c|c|c|c|}
\hline & 2008 & 2009 & 2010 & 2011 & 2012 & 2013 & 2014 & 2015 & 2016 & 2017 & TOTAL \\
\hline Area controlled for rats in monarch territories (ha) & $4^{1}$ & 39 & 70 & 116 & 124 & 115 & 132 & 143 & 143 & 128 & \\
\hline Number of rat bait stations & 325 & 305 & 470 & 580 & 650 & 586 & 685 & 712 & 712 & 664 & \\
\hline Area controlled for cats (ha) & & & 28 & 82 & 90 & 165 & 194 & 263 & 312 & 494 & \\
\hline Number of cat traps & & & 12 & 32 & 30 & 50 & 78 & 98 & 105 & 114 & \\
\hline Number of cat-trap nights & & & 384 & 2496 & 1800 & 3120 & 5265 & 7740 & 23040 & 29475 & 73320 \\
\hline Number of cat-trap nights per ha & & & 13,54 & 30,31 & 19,90 & 18,94 & 27,08 & 29,40 & 73,85 & 59,67 & \\
\hline Number of cats trapped & & & 8 & 17 & 2 & 14 & 35 & 35 & 95 & 121 & 327 \\
\hline Number of cats trapped per 100 ha & & & 28,22 & 20,64 & 2,21 & 8,50 & 18,00 & 13,30 & 30,45 & 24,49 & 20,07 \\
\hline Trapping success (Number of captures per 100 trap nights) & & & 2,08 & 0,68 & 0,11 & 0,45 & 0,66 & 0,45 & 0,41 & 0,41 & 0,45 \\
\hline Minimum number of cat eliminated byothertools & & & 2 & - & 6 & 6 & 8 & 2 & 3 & - & 27 \\
\hline Number of cats sterilizated/ euthanazied in the villages & & & & & 10 & 9 & 9 & 3 & 50 & 23 & 104 \\
\hline
\end{tabular}


Feral cat control was initiated in 2010 after the observation that two out of 20 adult birds in the Managed Area had missing tails and that several birds disappeared inexplicably. The number of traps set increased from 12 in an area of 28 ha in 2010, to 114 on 494 ha in 2017 , with the number of trap-nights per annum increasing from 384 to 29,475 respectively (Table 1 ). The total number of cats trapped was 327 during the study with a mean trapping success of $0.45 \%$ (0.11-2.68\%). Twenty-seven cats were killed by other methods. The number of cats trapped per $\mathrm{km}^{2}$ increased in the first two years of the project, decreased between 2012 and 2015 (10.5 cat per km², range: 2.2-18) and increased again with the leg-hold trapping method in 2016-2017 (27.4 cat per km²; 24.5-30.4). Finally, 104 domestic and stray cats in the 2 villages of the island have been sterilized or euthanized.

\section{Fatu Hiva monarch population monitoring}

\section{Monarch population changes at the island scale in 2000-2014:}

The encounter rate of Fatu Hiva Monarch during surveys declined from 0.58 individual per point count in 2002 to 0.11 individuals in a five-month survey in 2007, the latter rate being confirmed by another five- month survey in 2009 (Table 2).

We monitored the territories identified during the island-scale surveys and observed a significant decline from 32 territories in 2007 to only seven territories in 2014 (79\% decline in seven years, or $11 \%$ per year; Figure 1 ). Two additional areas that were surveyed for territories in multiple years showed similar trends. The overall rate of decline between 2007 and 2014 is estimated as $86 \%$, a mean of $12 \%$ per year. During 2009, a total of 39,901 m of valley were surveyed (Figure 2) outside the Managed Area resulting in 21 birds (one bird for every $1,900 \mathrm{~m}$ of valley). Based on Hibiscus tiliaceus habitat distribution, we estimated a further 50,386 m of valley axis with suitable habitat on the whole island.

Assuming that the occurrence of Monarchs per m of valley length was constant between the surveyed and the non-surveyed areas, these unsurveyed valleys were predicted to hold an additional 26 birds. Therefore, the total population in 2009 was estimated at 47 individuals outside the management area (21 observed and 26 estimated), with a further 17 birds inside, totalling 64 individuals.

\section{Monarch population changes within Managed Area 2007 to 2017}

\section{Population and demographic trends:}

The Managed Area has been monitored intensively for birds since 2007 (Figure 3). The monarch population in the 405 ha of the Managed Area started from II individuals in 2007, increased to 21 in 2012, but subsequently declined to 18 in 2016, before increasing again to 22 in 2017 (Table 3 ). The corresponding number of monarch pairs holding territory increased from five in 2007

Table 2. Fatu Hiva Monarch survey results at the island scale (number of birds observed and number of point counts undertaken in surveys between 2002 and 2009).

\begin{tabular}{lllll}
\hline Survey year & $\begin{array}{l}\text { Number of point } \\
\text { counts }\end{array}$ & $\begin{array}{l}\text { Number of monarchs } \\
\text { observed }\end{array}$ & $\begin{array}{l}\text { Number of monarchs } \\
\text { per point count }\end{array}$ & $\begin{array}{l}\text { Observers } \\
\text { (unpubl. reports) }\end{array}$ \\
\hline 2002 & 120 & 70 & 0,583 & Blanvillain C. \\
2003 & 94 & 26 & 0,277 & Gouni A. \\
2005 & 63 & 19 & 0,302 & Salducci J.M. \\
2006 & 158 & 20 & 0,127 & Gouni A. \\
2007 & 326 & 36 & 0,110 & Allanic Y. \\
2009 & 172 & 19 & 0,110 & Le Barh M. \\
\hline
\end{tabular}




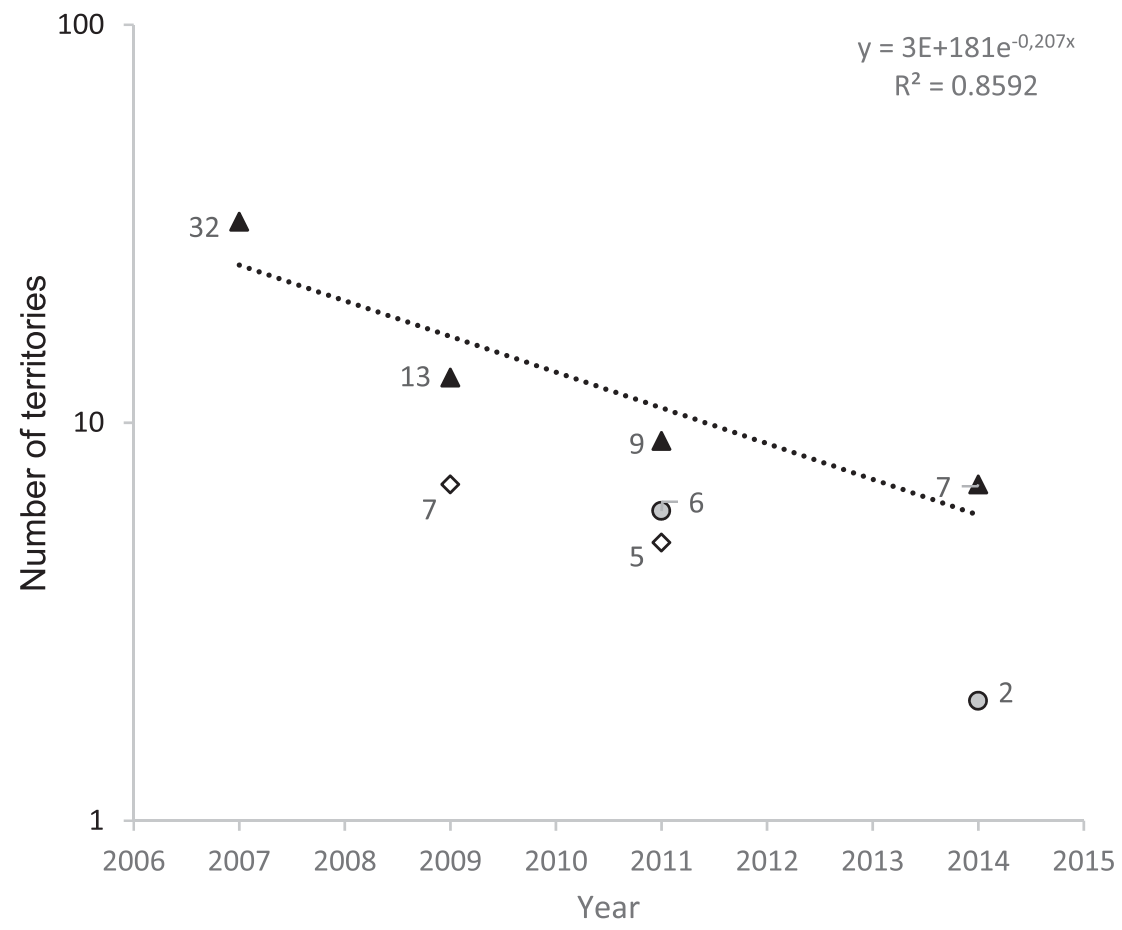

Figure 1 . Number of territories present in areas surveyed in multiple years (same areas monitored in multiple years are identified by the same symbol). Line indicates the mean rate of decline in number of territories.

(but with only two apparently fertile pairs) to eight in 2012, five in 2016 and six in 2017 (of which only one pair failed to breed in each year).

\section{Monarch breeding success:}

Data from pairs in areas without any predator control are very limited, as rat control was undertaken soon after discovery around each breeding pair. However, we made 16 observations of newly-discovered pairs prior to the establishment of rat control on these territories. These pairs showed no sign of active breeding (neither nest building, chick rearing nor fledgling observed). While this is a very small sample size, it suggests that, in absence of rat control, Fatu Hiva Monarch nesting success was low.

Considering the productivity of the monitored birds in the Managed Area, the number of fertile pairs (total number of pairs less the sterile pairs) varied between four and seven each year, with two to six pairs attempting incubation (Table 4). The pairs usually breed several times a year with a mean of $1.7(1-2.25)$ chicks hatching per pair per year. All nests observed at the chick stage revealed only one chick per nest. In total, 61 chicks hatched during the study, of which 54 fledged, and only 33 remained alive two months after fledging (mean of $61 \%$ fledgling alive; $40 \%-100 \%$ per year). The mean annual breeding success considering chicks that reached fledging was 0.84 chick/pair (0.33-1.29 per year). If survival until 2 months after fledging was taken into account, the mean breeding success declined to 0.52 juveniles per pair per year (0.17-1.0 per year), with the highest survival rates (1.o per pair per year) in 2016 and 2017. 




Figure 2. Map of Fatu Hiva island. Black lines represent valleys that were surveyed in 2009, dashed lines represent potentially suitable valleys, and the black area shows the Managed Area. The valley habitat is represented by the axis of the valleys, as the territories are centred on the streams.

\section{Recruitment:}

The first young birds were recruited into the breeding population in 2011 (Table 3), the timing corresponding with fledged juveniles produced in the first years of the conservation programme (2008-2010). Adults disappeared from the studied territories at a higher rate (3-5 per year) in 2008-2013 compared to 2014-2017 (0-1 per year). In 2011-2015, 11 individuals of 2-3 years old were observed in the Managed Area, seven $(63 \%)$ of them disappearing after only a few weeks or months. Recruitment improved in 2016-2017: six young were recruited and none of them disappeared.

\section{Mortality of chicks and fledged juveniles:}

In 2008-2017, 61 chicks hatched (Figure 4). The number of chicks that hatched annually peaked at 11 in 2013-2014, but has declined subsequently. Mortality in the nest appears low, with no 


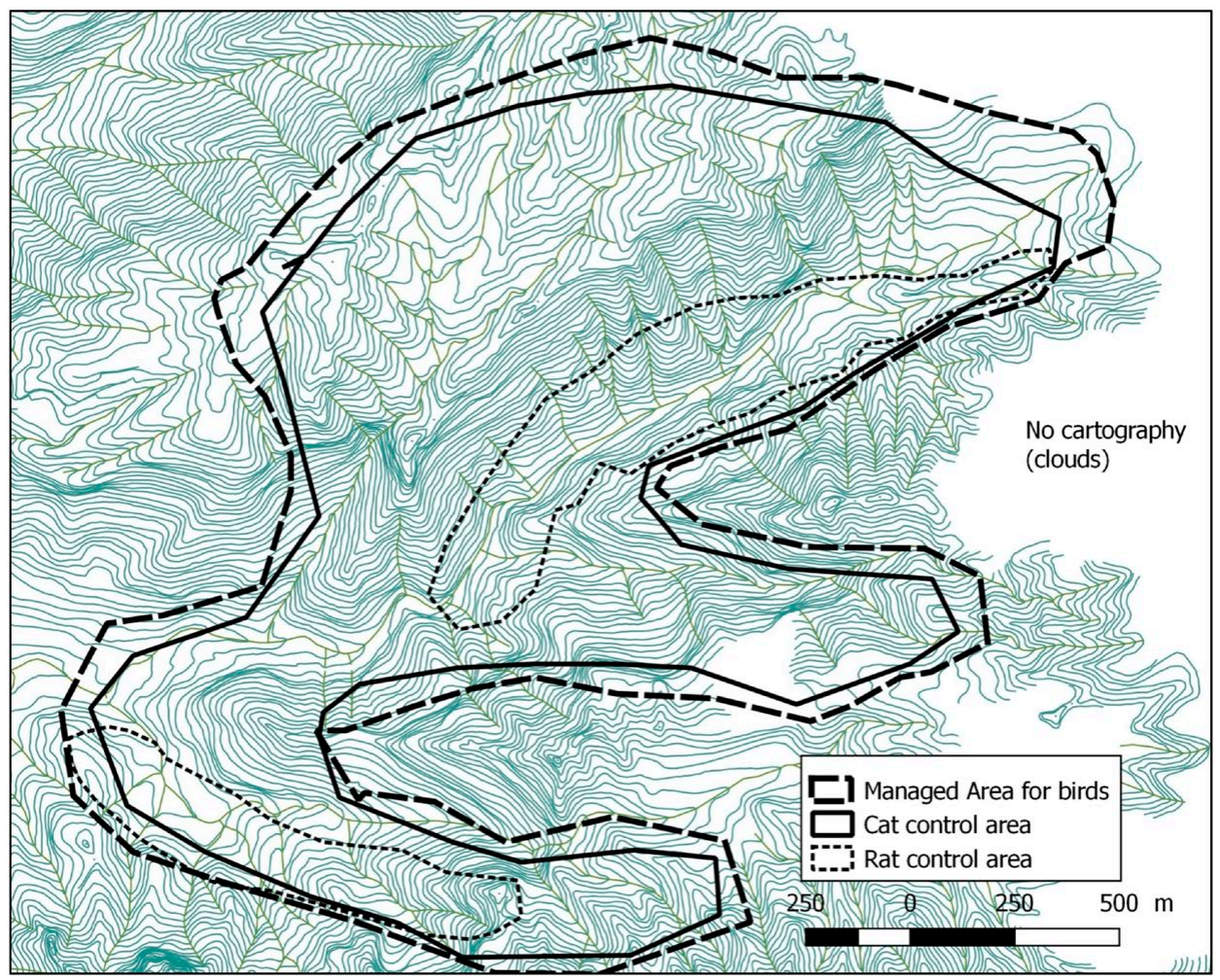

Figure 3. Map of the Managed Area on Fatu Hiva island including predator control areas (10 m between each contour line).

chick mortality in five of the nine years monitored. Mortality was generally high in the first two months after fledging, with between one and five fledged juveniles dying per annum in every year prior to 2016. In 2016-2017 all fledged juveniles survived for at least two months after leaving the nest. Reasons for the mortality of chicks and fledged juveniles in the Managed Area are:

- Seven (II\%) of the 61 chicks died in the nest. Rat predation is considered responsible for one chick death. Three chicks died as a result of inclement weather, two chicks died and were found on the ground with no signs of predation while two other chicks disappeared.

- Twenty-one (39\%) of the 54 fledged juveniles disappeared or were found dead in the first two months after leaving the nest. In 2008-2015, this rate was $48 \%$, compared to o \% mortality in 2016-2017 (Figure 4). Of the post-fledging losses, one juvenile was found with a broken wing, three were found dead on the ground, for reason other than predation, while circumstances around the remaining 17 are unknown.

\section{Adult survival:}

Ten adults (of at least three years old) were banded during the programme with colour bands allowing visual identification of individuals. In addition, two birds banded as juveniles survived to become adults. Any bird not recorded in a given year, was never subsequently located. Thus, we 
Table 3. Change in monarch abundance in the Managed Area during the conservation programme.

\begin{tabular}{|c|c|c|c|c|c|c|c|c|c|c|c|}
\hline & 2007 & 2008 & 2009 & 2010 & 2011 & 2012 & 2013 & 2014 & 2015 & 2016 & 2017 \\
\hline No. pairs & 5 & 6 & 6 & 6 & 7 & 8 & 7 & 7 & 6 & 5 & 6 \\
\hline No. unmated birds (territorial and floaters) & 1 & 3 & 5 & 7 & 5 & 5 & 6 & 6 & 8 & 8 & 10 \\
\hline No. birds in managed area (except yearlings) & 11 & 15 & 17 & 19 & 19 & 21 & 21 & 20 & 20 & 18 & 22 \\
\hline No. young birds ( $1-3$ years old) disappeared from territories & NA & o & o & o & o & 2 & 1 & 2 & 2 & o & o \\
\hline Total number of birds that disappeared (including adults) & NA & 5 & 3 & 5 & 3 & 6 & 4 & 2 & 3 & $\mathbf{I}$ & $\mathbf{1}$ \\
\hline No. young ( $1-3$ years old) recruited & NA & o & o & o & 4 & 3 & 1 & 2 & 1 & I & 5 \\
\hline Total number of birds recruited (including adults) & NA & 7 & 5 & 5 & 5 & 6 & 3 & 2 & $\mathbf{I}$ & $\mathbf{1}$ & 4 \\
\hline
\end{tabular}

Table 4. Summary of the Fatu Hiva Monarch productivity in the Managed Area from 2008 to 2017.

\begin{tabular}{|c|c|c|c|c|c|c|c|c|c|c|c|}
\hline & 2008 & 2009 & 2010 & 2011 & 2012 & 2013 & 2014 & 2015 & 2016 & 2017 & TOTAL \\
\hline No. of pairs & 6 & 6 & 6 & 7 & 8 & 7 & 7 & 6 & 5 & 6 & 64 \\
\hline Minimum No. of sterile pairs & $?$ & 1 & 1 & 1 & 1 & 1 & 1 & 1 & 1 & 1 & 9 \\
\hline No. of incubation events & 2 & 2 & 3 & 4 & 3 & 6 & 5 & 4 & 3 & 4 & 36 \\
\hline No. of hatched chicks & 2 & 3 & 6 & 5 & 3 & 11 & 11 & 9 & 5 & 6 & 61 \\
\hline$\%$ of juveniles alive at least 2 months after fledging & $50 \%$ & $50 \%$ & $50 \%$ & $40 \%$ & $67 \%$ & $5^{6 \%}$ & $63 \%$ & $38 \%$ & $100 \%$ & $100 \%$ & 61 \\
\hline Nesting success (No. of chicks fledged/ No. pairs monitored) & 0.33 & 0.33 & 1.00 & 0.71 & 0.38 & 1.29 & 1.14 & 1.33 & 1.00 & 1.00 & 0.84 \\
\hline \multirow{2}{*}{\multicolumn{12}{|c|}{ Breeding success (No. of juveniles alive to at least 2 months / }} \\
\hline & 0.17 & 0.17 & 0.50 & 0.29 & 0.25 & 0.71 & 0.71 & 0.50 & 1.00 & 1.00 & 0.52 \\
\hline
\end{tabular}






Figure 4. Number of chicks produced per year and proportion of individuals that died in the nest, or within two months of fledging.

can assume that birds not seen in a given year have died in that year. We estimated adult survival to be $88 \%$ ( 45 birds survived from year to $_{1}$ year $_{i+1}$ while six failed to survive).

\section{Comparison with demographic rates of other monarch species:}

Comparison of adult and nest (i.e. egg + chick) survival rates from two other, currently increasing monarch species indicated no significant difference among the three species (Figure 5; Robertson and Saul 2008, Blanvillain et al. submitted). However, post-fledging juvenile survival rates were markedly reduced in the Fatu Hiva Monarch (0.49 fledgling/pair) compared with the Tahiti (o.81 fledgling/pair) and Rarotonga (o.82 fledgling/pair) Monarchs. Consequently, the recruitment of young Fatu Hiva Monarchs into the breeding population was also low, with just 0.35 young recruited, half of the value for the other two species ( 0.67 and 0.77 , respectively). These results highlight that the survival of recently fledged Fatu Hiva Monarchs restricts the chances for population recovery.

\section{Discussion}

\section{Fatu Hiva Monarch population and demographic trends}

The Fatu Hiva Monarch population has declined catastrophically in the last 20 years to less than 30 birds in 2017, with only four active breeding pairs, all in the Managed Area. The species is literally on the brink of extinction. The relatively high nesting success produced 48 fledged juveniles between 2008 and 2016, of which $12(35 \%)$ were recorded in subsequent years (Table 2), most of these for a short time, and only five (10\%) have been effectively recruited into the breeding population (pers. obs.). This recruitment has not been sufficient to increase the population. Mortality of first year birds cannot be calculated with confidence given the limited data but mortality in the first two months after fledging (49\% in 2008-2015) was higher than that recorded for both Tahiti and Rarotonga Monarchs (16\% and 19\% respectively; Figure 5). Increasing the survival rate of 


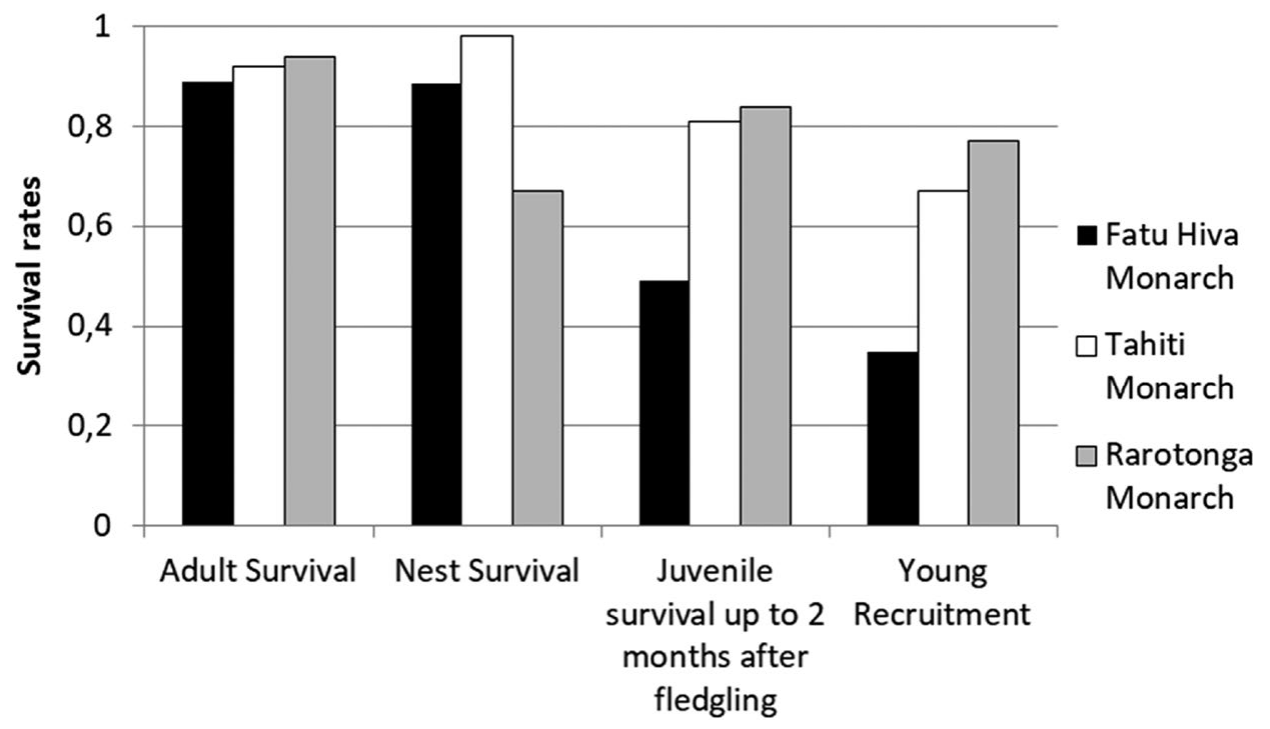

Figure 5. Survival rates of adult, nest (egg + chick stage), fledged juveniles within two months of leaving nest, and young recruitment rate in the population of three Pomarea species. Data for Fatu Hiva Monarch adult and nest survival: entire study period, fledging survival: 2008-2015 and recruitment rate: 2008-2016. For more details, see the methods section.

juveniles post-fledging is the highest priority, so the fact that all II chicks that fledged in $2016-$ 2017 survived beyond two months, and that five juveniles were recruited into the population in 2017 , support the continued implementation of the current management regime.

\section{Effect of rat control}

Rat predation of nests has not been significant during the programme, due to the levels of control undertaken. Our initial assumption that controlling rats would improve breeding success, as observed for Tahiti and Rarotonga Monarchs, proved to be correct. However, in contrast to studies on the latter species, the improvement in breeding success for Fatu Hiva Monarch has not resulted in population increase. An alternative suggestion is that rats may predate roosting birds at night. Black rats are known to be aggressive arboreal predators that may opportunistically attack roosting passerines (Townsend et al 2009, Dhondt et al 2010). This form of predation has not been reported for smaller monarchs on other islands (Saul, pers. comm., Blanvillain pers. obs.). We assume that rat predation is not responsible for the mortality of post-fledged juveniles at roost in the parent territory. Rat trapping suggested a near 1o-fold reduction in the number of rats in parts of the Managed Area where rats were controlled ( 1.6 captures/100 trap nights, $n=5,111$ in 2014 versus 10.1/100 trap nights in an area without rat control, $n=128$ in 2009; unpubl. report). A concern now is that rat numbers in the area where cats, but not rats, were controlled are higher. This may make the area more attractive to cats and thereby increase the effort required to maintain cat numbers at a low level.

\section{Effect of cat control}

Observations in 2013-2014 recorded immature and sub-adult monarchs in the Managed Area following improved nesting success in 2008-2012 (Figure 4). Subsequent recruitment has been much reduced in 2013-2016. Prior to 2016, the programme was primarily implemented in the 
field by SOP Manu workers based on Fatu Hiva, with occasional visits from staff from HQ. Initially we presumed that young birds moved outside the Managed Area. Young Rarotonga and Tahiti Monarchs are known to move to the ridges of the valleys and only come back to set up their own territory near the streams after 12-36 months (Robertson et al. 1994, Blanvillain et al. 2017). However, subsequent years of monarch monitoring in the Managed Area and the extensive surveys conducted at the island scale have resulted in no new sightings of individuals away from the Management Area. This situation has been highlighted in a number of other studies of island avifauna (Nogales et al. 2004, Bonnaud et al. 2010, Medina et al. 2011, Doherty et al. 2015). As a consequence, we hypothesise that at least some of the unexplained $67 \%$ mortality in young monarchs could be due to predation by cats. This hypothesis seems to be supported by the high numbers of cats in the cat control area (286 cats trapped in the last three years of the study; Table 1 ) and by the observation of adult monarchs with no tail and territorial individuals disappearing suddenly without explanation. In addition, the inquisitive nature of the young birds renders them particularly susceptible to predation by cats.

Cat control started on Fatu Hiva in 2010 using kill traps and although 111 cats have been trapped in the first six years with these tools (Table I), the supposed mortality of young monarch chicks remained high (Table 4). It seems likely that the secondary poisoning of cats, expected from rat poisoning with Brodifacoum baits (Alterio 1996, Nogales et al. 2004) was effective in reducing cat numbers at the start of the project, although we did not collect information to quantify this impact at the time. Trap shyness of cats, the low number of traps per hectare and the limited trapping effort (due to resources and bait palatable over a short term) might explain why this method failed to keep cat densities low in the Managed Area in 2010-2015. At the end of 2015, we switched from kill traps to leg-hold traps which along with the consequent three-fold increase in effective trapping effort in 2016-2017, increased the numbers of cats trapped (Table 3). Leg-hold traps are known to be more efficient at catching cats than kill traps (Lee 1995, Denny and Dickman 2010, Campbell et al. 2011). This switch also coincided with an increase in post-fledging survival in the monarch (Table 4), with no disappearance of immature birds in 2016-2017 (compared with 1.75 immatures per year disappearing in 2012-2015; Table 3) and with only one adult disappearing per year in 2016-2017 (compared to three per year in 2008-2015; Table 2). The young produced in 2016-2017 have been regularly checked and were still present within the Managed Area 8-11 months after fledging. This is the first time since 2008 that we have observed more than one fledged juvenile present more than 2-4 months after the nesting period in any given year.

Controlling feral cats is a complex process (Recio et al. 2017). Some studies have shown a negative effect of low-level culling of cats in open populations, with locally higher cat abundances after control than before (Sinclair et al. 2006, Lazenby et al. 2014). A reduction in cat numbers has generally only been obtained after sustained and intensive efforts (Algar and Burrows 2004). In the case of Fatu Hiva, it was not possible to observe the impact of cats on the monarch annual survival rates directly or quantify the level of both rat and cat control that would be required to increase nest, chick and post-fledging survival rates significantly. Nevertheless, based on the information presented here, we consider it likely that the cat control implemented in 2010-2014 was insufficient to significantly affect cat abundance and may even have led to higher local cat densities after trapping by replacing the dominant territory-holding individuals with influxes of new individuals, as shown by Lazenby et al. (2014) in the case of a low-level culling operation. The high number of cats trapped in 2016-2017 (216 cats on 400 ha with 66 trap nights per ha per year), combined with the favourable results of monarch fledging survival and recruitment rate in these years lends support to the idea that control undertaken before this year (maximum of 40 trap nights per ha) had been insufficient. Alternatively, or in addition, the area of cat control may previously have been too small, a conclusion that is supported by other studies (Algar and Burrows 2004, Bengsen et al. 2012, Lazenby et al. 2014).

Finally, introduced rodents generally constitute a reliable prey source that can facilitate the expansion of abundant feral cat populations, and may indirectly increase predation risk for native species through the "hyper-predation" mechanism (Courchamp et al. 1999, Ringler et al. 2015). 
The high abundance of cats caught in the cat-control area during the study suggests that this mechanism may be operating on Fatu Hiva, maybe exacerbated by the possibility of a high density of black rats outside the rat control area, but inside the area controlled for cats. Analysis of rat densities in a) the rat control area, b) the wider cat control area and c) in an adjacent valley would provide insight into the impact of the different levels of control in and around the Management Area.

Clearly, we need to collect more information over the next 2-3 years to confirm that:

1) High post-fledging mortality in monarchs is, in fact, associated with high numbers of cats, and that reduced cat numbers in the management area continues to correlate with improved survival rates

2) The lack of survival post-fledging causes the lack of recruitment into the population, and so the lack of any population increase. By increasing the survival rate we should see an increase in recruitment and ultimately an increase in the population of the species.

3) We are undertaking the most effective method for reducing post-fledging and juvenile mortality of the monarch. We need to consider whether the scale and effort of cat control undertaken in 2016-2017 is the most effective way to increase post-fledging survival. We currently deploy a combination of trail cameras and continuous trapping in the external part of the Managed Area. We monitor the trail cameras twice a week to identify any cat incursions in the centre of the Managed Area. When an incursion is recorded we set the leg-hold traps. This helps to target and optimise the cat control programme. We need to determine how an integrated pest management approach can be implemented most effectively, given the limited resources.

\section{Conclusion and perspectives}

The Fatu Hiva Monarch conservation programme, initiated in 2007, has prevented the immediate extinction of the species. It seems likely that the rat control programme increased breeding success sufficiently to reduce the rate of decline but that the population has not subsequently increased. Current evidence indicates that low post-fledging survival limits monarch population recovery. We continue to test the hypothesis that high intensity cat control can improve postfledging survival sufficiently to enable the population to increase. The area controlled for rats is limited to the current and recent monarch territories and has been effective at ensuring nest survival rates comparable with other, currently increasing, monarch populations. However, the possibility remains that rats may be predating roosting birds, and that high densities of rats in the area adjacent to the control area (where cat control is maintained) may result in both an increase in numbers of cat incursions and a reduction in the attractiveness of new territories. This would suggest that we should increase the area controlled for rats to include the entire area managed for the bird (i.e. from 143 to 405 ha). We will need to assess whether the extra effort required to maintain 400 ha of low rat density is cancelled out by the reduction in the effort required to maintain a low cat density.

The 2016-2017 breeding attempts showed encouraging results in terms of young monarch survival rates. We will need to repeat this effort over the next two years and over a larger area to confirm that monarch populations increase in areas where both effective rat and cat control are undertaken. The use of leg-hold traps to control cats is time consuming but has proved to be effective. Investigating the most effective means of delivering this level of control is necessary if we are to increase the monarch population and enable a long-term solution to be developed. Alternative methods of controlling cats, such as the use of Predastop@ have been trialled but have not proved to be effective without devices preventing access to rats and pigs.

In the long term we need to increase the population of monarchs to provide a source population either as a source for translocation to a rat- and cat-free island, or for the recolonisation of the remaining habitat on Fatu Hiva following the eradication of black rats from the island. Rat and cat 
eradication from the whole island of Fatu Hiva, although very difficult and expensive, would be technically possible (Saunders 2013). The first step, to ensure community acceptance of removing both cats and rats, is currently underway (Boudjelas 2018). Multi-species eradications can provide cost savings not just in terms of conservation action, but also for the community (Griffiths 2011). Major issues that the community would need to consider include the impact of an eradication attempt on the wild pigs and goats present throughout the island - a significant source of protein for the community.

\section{Acknowledgements}

Department of Conservation (New Zealand) provided spare traps and free training for SOPManu staff. Pacific Invasives Initiative (Souad Boudjelas) supported the programme with their network and technical help. BirdLife International, Island Conservation (especially Jason Zito) and Auckland Zoo shared their experience in conservation strategy or cat control. These organisations and people need to receive warm acknowledgement as well as Judit Szabo and Michael Lee, referees on the manuscript, and James Russell and Eric Vidal who provided additional advice on the article. This programme was supported by many funders over eight years, the main ones being: French Polynesia government through DIREN, European Union (BEST 1.o Grant $\mathrm{N}^{\circ}$ 07.032700 \& BEST 2.0 Grant $N^{\circ}$ 1058), Critical Ecosystem Partnership fund (Grant $N^{\circ}$ 58208), Auckland Zoo conservation fund, Birdfair, BirdLife International, BirdLife International Community Conservation Fund, French Ministry of Environment, CEPA, Zoos Victoria, ZGAP, PDCT, Jensen Foundation, Prince Bernard Nature Fund, Fatu Hiva Council and many other commercial partners (Air Tahiti, Aranui, T Gear, Animal Control Products Ltd,) and private people through sponsorship of banded birds. We thank all these funders and supporters for their continued support. Many thanks also to Service de l'Aménagement et de l'Urbanisme for providing Fatu Hiva map data. Every field worker, volunteer or student needs to be acknowledged here (especially M. Terorohauepa, I. Tauapaohu and R. Luta), and also many people from SOP Manu have taken part in the annual surveys (A. Gouni, P. Raust, J. M. Salducci, Y. Allanic).

\section{References}

Algar, D. and Burrows, N. D. (2004) Feral cat control research: Western Shield review. Conserv. Science 2: 131-163.

Alterio, N. (1996) Secondary poisoning of Stoats (Mustela erminea), feral Ferrets (Mustela furo), and feral House Cats (Felis catus) by the anticoagulant poison, brodifacoum. New Zealand J. Zool. 23: 331-338.

Bengsen, A., Butler, J. and Masters, P. (2012) Applying home-range and landscape-use data to design effective feral-cat control programs. Wildl. Res. 39: 258-265.

Bibby, C., Burgess, N., Hill, D. and Mustoe, S. (2000) Bird census techniques. Second edition London: Academic Press.

BirdLife International (2018) Species factsheet on Pomarea spp. Downloaded from http:// www.birdlife.org on 26/11/18.

Blanvillain, C, Ghestemme, T., Withers, T. and O'Brien, M. (2017) Breeding biology of the critically endangered Tahiti monarch Pomarea nigra, a bird with a low productivity. Bird Conserv. Internatn. 1-14. Doi: 10.1017/W095927091700048X

Blanvillain, C, Ghestemme, T., Saavedra, S., Yan, L. and O'Brien, M. (submitted). Recovery of the Tahiti monarch, Pomarea nigra: A critically endangered forest bird of Tahiti Island.

Bonnaud, E., Zarzoso-Lacoste, D., Bourgeois, K., Ruffino, L., Legrand, J. and Vidal, E. (2010) Top-predator control on islands boosts endemic prey but not meso predator. Anim. Conserv. 13: 556-567.

Boudjelas, S. (2018) Analyse de l'enquête sur le projet d'éradication des rats et chats sur l'île de Fatu Hiva. Unpub. report. SOP Manu.

Brooke, M. de L., Hilton, G. M. and Martins, T. L. (2007). Prioritizing the world's islands 
for vertebrate-eradication programme. Anim. Conserv. 10: 380-390

Campbell, K. J., Harper, G., Algar, D., Hanson, C., Keitt, B. and Robinson, S. (2011) Review of feral cat eradications on islands. Pp. $37-46$ in C. R. Veitch, M. N. Clout and D. R. Towns, eds. Island invasives: eradication and management. Proceedings of the International Conference on Island Invasives. Gland, Switzerland: IUCN and Auckland, New Zealand: CBB.

Collar, N. J. Crosby, M. J. and Stattersfield, A. J. (1994) Birds to watch 2: the world list of threatened birds: the official source for birds on the IUCN red list. Cambridge, UK: BirdLife International. (BirdLife conservation series $n^{\circ} 4$ ).

Cibois, A., Thibault, J. C. and Pasquet, E. (2003) Biogeography of eastern Polynesian monarchs (Pomarea): an endemic genus close to extinction. Condor 106: 837: 851.

Courchamp, F., Langlais, M. and Sugihara, G. (1999) Control of rabbits to protect island birds from cat predation. Biol. Conserv. 89: 219-225.

Cox, W. A., Thomson, F., Cox, A. and Faaborg, J. (2014) Post-fledging survival in Passerine birds and the value of post-fledging studies to conservation. J. Wildl. Manage. 78 : 183-193.

Denny, E. and Dickman, C. R. (2010) Review of cat ecology and management strategies in Australia. Canberra: Invasive Animals Cooperative Research Centre.

Dhondt, A. A., Blondel, J. and Perret, P. (2010) Why do Corsican Blue Tits Cyanistes caeruleus ogliastrae not use nest boxes for roosting? J. Ornithol. 151: 95.

Doherty, T. S., Bengsen, A. J. and Davis, R. A. (2015) A critical review of habitat use by feral cats and key directions for future research and management. Wildl. Res. 41: 435-446.

Efford, M. G. and Fewster, R. M. (2013) Estimating population size by spatially explicit capture-recapture. Oikos 122: 918-928.

Ghestemme, T., Blanvillain, C. and O'Brien, M. (2013) Species Action Plan - Fatu Hiva Monarch 2013-2018. SOP-Manu/BirdLife International. Unpubl. report.

Griffiths, R. (2011) Targeting multiple species a more efficient approach to pest eradication.
Pp. $172-176$ in C. R. Veitch, M. N. Clout and D. R. Towns, eds. Island invasives: eradication and management. Proceedings of the International Conference on Island Invasives. Gland, Switzerland: IUCN and Auckland, New Zealand: CBB.

Holyoak, D. T. and Thibault, J. C. (1984) Contribution à l'étude des oiseaux de Polynésie orientale. Mémoires du Museum National d'Histoire Naturelle 127: 1-209. Laurent, V. (2016) Climat aux Iles Marquises. Pp. $105-122$ in R. Galzin, S. D. Duron and J. Y. Meyer, eds. Biodiversité terrestre et marine des îles Marquises. Paris: Société française d'Ichtyologie.

Lazenby, B., Mooney, N. and Dickman, C. (2014) Effects of low-level culling of feral cats in open populations: a case study from the forests of southern Tasmania. Wildl. Res. 41: 407-420.

Lee, J. (1995) Evaluation of trapping as a control method for feral cats. AWMS Newsletter 8: 17 .

Medina, F. M., Bonnaud, E., Vidal, E., Tershy, B., Zavaleta, E., Donlan, C., Keitt, B., Le Corre, M., Horwath, S. and Nogales, M. (2011) A global review of the impacts of invasive cats on island endangered vertebrates. Global Change Biol. 17: 3503-3510.

Murphy, R. C. and Mathews, G. M. (1928) Birds collected during the Whitney South Sea expedition. Vol 5. Am. Mus. Novitates. The Am. Mus. of Natural History. Vol 337.

Nogales, M., Martin, A., Tershy, B., Donlan, C., Veitch, D., Puerta, N, Wood, B. and Alonso, J. (2004) A review of feral cat eradication on islands. Conserv. Biol. 18: 310-319.

Nogales, M., Vidal, E., Medina, E., Bonnaud, E., Tershy, B., Campbell, K., Zavaleta, E. (2013) Feral cats and biodiversity conservation: the urgent prioritization of island management. Biosciences 63: 804-810.

Recio, M., Maloney, R., Mathieu, R., Virgos, E., Moore, T., and Seddon, P. (2017) Optimizing control programmes by integrating data from fine-scale space use by introduced predators. Biol. Invasions. DOI: 10.1007/ S10530-016-1274-3

Ringler, D., Russell, J. C. and Le Corre, M. (2015) Trophic roles of black rats and seabird impacts on tropical islands: mesopredator 
release or hyperpredation? Biol. Conserv. 185: 75-84.

Robertson, H. A. and Saul, E. K. (2008) Conservation of Kakerori in the Cook Islands in 2006/07. Wellington: Department of Conservation. (DOC Research \& Development series $\mathrm{N}^{\circ} 296$ ).

Robertson, H. A., Hay, J. R. and Saul, E. K. (1993) Age and sex determination of Kakerori Pomarea dimidiata. Notornis 40: 179-187.

Robertson, H. A., Hay, J. R., Saul, E. K. and MacCormack, G. (1994) Recovery of Kakerori: an endangered forest bird of the Cook Islands. Conserv. Biol. 8: 1078-1086.

Saunders, A. (2013) Managing invasive species to recover Polynesian monarchs: achievements and future directions. Hamilton, New Zealand: Landcare Research. Unpubl. report.

Seitre, R. and Seitre, J. (1992) Causes of land bird extinction in French Polynesia. Oryx 6: $215-222$.

Sinclair, A., Fryxell, J. and Caughley, G. (2006) Wildlife ecology, conservation and management. 2nd edition. Oxford: Blackwell Publishing.

Steadman, D. W. (2006) Extinction and biogeography of tropical Pacific birds. Chicago: University of Chicago Press.

Thibault, J.-C. and Cibois, A. (2017) Birds of Eastern Polynesia: A biogeographic atlas. Barcelona: Lynx Edicions.

Thibault, J.-C. and Meyer, J.-Y. (200I) Contemporary extinction and population declines of the monarchs (Pomarea spp.) in French Polynesia, South Pacific. Oryx 35: 73-80.

Thibault, J.-C., Martin, J. L., Penloup, A. and Meyer, J. Y. (2002) Understanding the decline and extinction of monarchs (Aves) in Polynesian Islands. Biol. Conserv. 108: 161-174.

Townsend, J. M., Rimmer, C. C., Brocca, J., McFarland, K. P. and Townsend, A. K. (2009) Predation of a wintering migratory Songbird by introduced rats: can nocturnal roosting behavior serve as predator avoidance? The Condor 111: 565-569.

THOMAS GHESTEMME*, ARTHUR MATOHI, CAROLINE BLANVILLAIN, EMMANUELLE PORTIER, MADEN LE BARH

Société d'Ornithologie de Polynésie (SOP Manu), Taravao, French Polynesia.

MARK O'BRIEN

BirdLife International (Pacific Partnership Secretariat), Suva, Fiji.

*Author for correspondence; e-mail: tghestemme@manu.pf

Received 20 March 2018; revision accepted 1o February 2019; Published online 18 March 2019 